\title{
HIV-Related Knowledge, Attitude and Practices of Healthy Adults in Cross River State Nigeria: A Population Based-Survey
}

\author{
Uchenna Okonkwo*, Soter Ameh, Akaninyene Out and Henry Okpara
}

University of Calabar Teaching Hospital, Calabar, Nigeria

\begin{abstract}
Background: Human immunodeficiency virus (HIV) remains a global health problem disproportionately distributed across Nigeria. Cross River State (CRS), a tourist state, located in the Niger delta, has one of the highest prevalence rates. There is evidence that poor knowledge and stigmatization are obstacles to achieving universal access to HIV prevention programs.
\end{abstract}

Objective: The aim of this study was to determine the Knowledge, Attitude and Practice (KAP) of HIV among adults resident in CRS, Nigeria.

Methods: A cross sectional descriptive survey design was employed. A total of 1,620 healthy adults were recruited. KAP towards HIV was assessed using a structured pre-tested questionnaire. Categorical variables were described as frequencies and continuous variables as median and interquartile range. Kruskal-Wallis test was used to determine relationship between variables and median KAP scores. $\mathrm{P}$ value $<0.05$ was considered significant. All analyses were performed using Stata 12 statistical package.

Results: A total of 1,465 respondents completed the questionnaire correctly giving a response rate of $91 \%$. The $\mathrm{M}$ : $F$ ratio was 1:1.8. The median age was 38 years. Majority was married and had formal education. Knowledge of HIV and common routes of transmission was high $(>80 \%)$. However, misconception that HIV can be transmitted through hugging, hand shake, mosquito bites and witch craft was also common $(>60 \%)$. The overall attitude and practice towards persons living with HIV infection was poor.

Conclusion: This study showed misconceptions in the knowledge and consequences of HIV infection which is associated with negative attitude towards persons living with HIV.

Keywords: HIV; Knowledge; Attitude and practice; Nigeria

\section{Introduction}

Human immunodeficiency virus (HIV) is a global epidemic currently affecting approximately 37 million persons [1]. Since the beginning of the epidemic in the $80 \mathrm{~s}$, more than 70 million people have been affected and 35 million of them have died [2]. Although tremendous progress has been made in combating the pandemic globally with a $43 \%$ reduction in the annual Acquired immunodeficiency syndrome (AIDS) related mortality, huge challenges still lie ahead [1]. The burden of HIV/AIDS is not evenly distributed across or within countries and regions. Sub-Saharan Africa is the region of the world most severely affected by HIV/AIDS accounting for $70 \%$ of people living with HIV/ AIDS (PLWHA) worldwide. This translates to almost 1 in every 25 adults (4.4\%) living with HIV in the region [2].

Nigeria being the most populous country in sub-Saharan Africa is home to 3.5 million people with HIV infection accounting for $9.4 \%$ of the global population of PLWHA. Although, the adult HIV prevalence in Nigeria is relatively low at $3.1 \%$ compared to other African countries such as Zambia, South Africa and Chad with two digit prevalence rates, an estimated 250,000 new infections and 180,000 AIDS related deaths were recorded in Nigeria in 2015 with most of them in persons aged 15-49 years [3]. In spite of these disturbing figures, the National HIV/ AIDS and Reproductive Health survey of 2012 showed that uptake of HIV testing is low with just $23 \%$ of males and $29 \%$ of females knowing their status [4]. In addition, only $24 \%$ of adults who were HIV positive were receiving anti-retroviral drugs. Thus, over $70 \%$ of infected persons remain untreated and serve as sources of new infection.

Cross River State (CRS) located in the south-south geographical region of Nigeria is known for its' many international festivals of which the most notable is the annual carnival float which attracts tourists from all over the world. CRS had one of the highest prevalence rates of HIV in the country at the outset of the epidemic. However, with concerted efforts by the government and its agencies, the prevalence of HIV had dropped from $12 \%$ in 2003 to $6.9 \%$ in 2014 [5]. Nonetheless; this is still higher than the national average of $3.1 \%$. Some of the drivers of this epidemic in the State include high risk sexual behavior and low risk perception of HIV and its consequences [6]. The Cross River State Agency for the Control of AIDS (CRSACA) reported that $75 \%$ of the population in the State do not perceive themselves as being personally at risk of HIV infection [7].

Unprotected heterosexual sex is the predominant mode of HIV transmission in Nigeria accounting for about $80 \%$ of new HIV infections [8]. Majority of the rest occurs among minority groups such as sex workers, men who have sex with men and intravenous drug users. Although these groups make up less than $2 \%$ of the Nigerian population, yet they account for around $23 \%$ of new HIV infections $[9,10]$. Unsafe injection practices and mother-to-child transmission

*Corresponding author: Dr. Okonkwo Uchenna, Senior Lecturer, Gastroenterology/Hepatology unit, Department of Internal Medicine, University of Calabar Teaching Hospital, P.M.B. 1278, Calabar, Cross River State, Nigeria, Tel: 2348033251240; E-mail: ucsuizes@yahoo.co.uk

Received May 17, 2016; Accepted May 23, 2017; Published May 30, 2017

Citation: Okonkwo U, Ameh S, Out A, Okpara H (2017) HIV-Related Knowledge, Attitude and Practices of Healthy Adults in Cross River State Nigeria: A Population Based-Survey. J AIDS Clin Res 8: 699. doi: 10.4172/2155-6113.1000699

Copyright: (c) 2017 Okonkwo U, et al. This is an open-access article distributed under the terms of the Creative Commons Attribution License, which permits unrestricted use, distribution, and reproduction in any medium, provided the original author and source are credited. 
are other significant modes of transmission [11,12]. Transfusion of unscreened blood or blood products is reported not to be a major source of new infection [13].

Studies in Nigeria among segments of the general population have shown that while knowledge of the nature of HIV is high, practice of unsafe sexual behavior is common and is associated with low knowledge of modes of transmission and risk perception [14-16]. The Nigerian Ministry of Health in 2013, reported that only $24 \%$ of young people could correctly identify ways to prevent sexual transmission of HIV and reject common myths [4]. Moreover, the attitude towards PLWHAs is generally negative even among healthcare workers [1619]. The United Nations as part of its Sustainable Development Goals, committed to ending the HIV epidemic by 2030 [20]. For Nigeria to achieve this mandate, KAP studies are necessary to develop suitable health promotion interventions to facilitate health behavior change. It is hoped that this study will add to available knowledge and help promote already existing efforts in the fight against HIV/AIDS.

\section{Aims and Objective}

The aim of this study was to determine the Knowledge, Attitude and Practice of HIV among adults resident of CRS, Nigeria.

\section{Methods}

\section{Study setting}

CRS is located in the Niger delta region of Nigeria. There are 18 local government areas (LGAs) in CRS divided into three senatorial districts: Southern, Central and Northern senatorial districts. There are 6 LGAs per senatorial district and these are: Akamkpa, Akpabuyo, Bakassi, Calabar Municipal, Calabar South and Odukpani in the southern district, Abi, Biase, Boki, Etung, Ikom and Yakuur in the central district, Obanliku, Obubra, Obudu, Ogoja, Bekwarra, and Yala in the northern district. Each LGA comprises 10 wards.

\section{Study design}

This was a cross sectional study conducted between March and September, 2015.

\section{Study population}

The study population consisted of adult men and women (aged 18years and above) resident in CRS.

\section{Inclusion and exclusion criteria}

Individuals residing in the selected LGAs who were aged 18 years and above and provided written informed consent were included in the study while those not meeting these criteria were excluded.

\section{Sample size estimation}

A prevalence of $12 \%$, confidence interval of $95 \%$ and degree of $5 \%$ was substituted into the Leslie and Kish formula, $n=z^{2} p(1-p) / d^{2}$ to determine the sample size. An attrition rate of $10 \%$ was added and rounded up to 180 persons per LGA. These number of persons were recruited in the nine LGA studied to give a total of 1620 .

\section{Sampling technique}

A stratified random sampling technique was employed. Three LGAs were randomly selected from the three senatorial districts. There were Calabar south, Akamkpa and Akpabuyo from the south, Abi, Ikom and Yakurr from the central, Ogoja, Obudu and Yala from the north. In each of the LGAs, three wards were randomly selected except in one LGA where 5 wards were selected for ease of access. A total of 29 wards in 9 LGAs in 3 senatorial districts were sampled.

\section{Data collection}

A structured 35 item questionnaire divided into three sections (excluding the demographic section) was used for data collection. It comprised of 27 questions on knowledge of HIV, 5 questions on attitude and 3 questions on practices towards PLWHA. The questionnaire was developed following extensive literature review and pre-tested for reliability and validity.

\section{Statistical analysis}

Data was entered into Microsoft Excel 2013 and imported into Stata 12.0 (College Station, TX, USA) for statistical analyses. It was declared as survey data by using the "svyset" Stata syntax before commencement of statistical analysis in order to minimize underestimation of the standard error arising from the survey design of the study. Continuous variables were reported in median and interquartile range because of the skewed nature of the data which was determined by Kolmogorov-Smimov test, whereas categorical variables were presented in frequencies (n) and relative frequencies (\%). For knowledge and practice questions, a score of 1 was given to "yes" correct responses while a score of 0 was given to "no" incorrect responses. On the other hand, a score of 1 was assigned to 'No' correct responses, whereas a score of 0 was assigned to 'yes' incorrect responses (e.g. can HIV be transmitted through witchcraft?). For attitude questions, a score of 1 was assigned to 'disagree' responses while a score of 0 was given to 'agree' responses (e.g. non-infected persons should not work in the same office as HIV patients). The range of scores for knowledge, attitude and practice were $0-27,0-5$ and $0-3$, respectively. The KAP scores were categorized as follows; for knowledge, score of $0-10=$ knowledge is minimum, $11-20=$ knowledge is adequate, $>20=$ knowledge is very good. Attitude score of $0-2=$ attitude is negative, $3-4=$ attitude is fairly positive, $>4=$ attitude is very positive. Practice score of $0-2=$ practice is poor, $>2=$ practice is good. Spearman correlation was used to assess the relationship between knowledge, attitude and practice scores. Kruskal-Wallis test was used to determine relationship between variables and median KAP scores. All statistical tests were undertaken at $5 \%$ significance level.

\section{Ethical consideration}

Ethical approval was obtained from the Cross River State Health Research Ethics Committee (CRS-HREC) with reference number $\mathrm{RP} / \mathrm{REC} / 2015 / 281$. Respondents' anonymity and confidentiality was maintained throughout the course of the study.

\section{Results}

A total of 1,465 respondents completed the questionnaire correctly giving a response rate of $91 \%$. There were 928 females (63.3\%) and 517 males $(35.3 \%)$. Twenty persons $(1.36 \%)$ did not indicate their gender. The median age of the study participants was 38years. More than half were married and had formal education. There were 520 (35.4\%), 517 (35.2\%) and 428 (29.2\%) respondents from the southern, northern and central senatorial districts, respectively (Table 1).

The majority of the respondents (92\%) had heard of HIV but only $52 \%$ were aware that it causes chronic infection. The knowledge of the modes of transmission of HIV was also high at $90 \%$ for sexual route, $88 \%, 87 \%$ and $81 \%$ for blood transfusion, sharps and motherto-child transmission, respectively. Nonetheless, 78\%, 67\% and 62.5\% responded erroneously that HIV could be transmitted through hugging, handshake, mosquito bites and witchcraft. Concerning knowledge 
Citation: Okonkwo U, Ameh S, Out A, Okpara H (2017) HIV-Related Knowledge, Attitude and Practices of Healthy Adults in Cross River State Nigeria: A Population Based-Survey. J AIDS Clin Res 8: 699. doi: 10.4172/2155-6113.1000699

Page 3 of 5

\begin{tabular}{|c|c|c|c|c|c|}
\hline Variable & $\begin{array}{l}\text { Total } \\
\text { N (\%) }\end{array}$ & $\begin{array}{c}\text { Southern district } \\
N(\%)\end{array}$ & $\begin{array}{c}\text { Central district } \\
\text { N (\%) }\end{array}$ & $\begin{array}{c}\text { Northern district } \\
\mathrm{N}(\%)\end{array}$ & $\begin{array}{l}\text { Design effect adjusted } \\
\text { p-value of difference }\end{array}$ \\
\hline $\begin{array}{l}\text { Age group in years (median; } \\
\text { IQR) } \\
18-27 \\
28-37 \\
38-47 \\
48-57 \\
>57\end{array}$ & $\begin{array}{l}(38 ; 27-50) \\
373(25.5) \\
315(21.5) \\
318(21.7) \\
216(14.7) \\
168(11.5)\end{array}$ & $\begin{array}{c}(35 ; 26-45) \\
156(30.0) \\
109(21.0) \\
128(24.6) \\
72(13.8) \\
26(5.0)\end{array}$ & $\begin{array}{c}(40 ; 30-55) \\
69(16.1) \\
100(23.4) \\
89(20.8) \\
67(15.6) \\
88(20.6)\end{array}$ & $\begin{array}{l}(35 ; 25-49) \\
148(28.6) \\
106(20.5) \\
101(19.5) \\
77(14.9) \\
54(10.5)\end{array}$ & 1.000 \\
\hline $\begin{array}{l}\text { Sex } \\
\text { Female } \\
\text { Male }\end{array}$ & $\begin{array}{l}928(63.3) \\
517(35.3)\end{array}$ & $\begin{array}{l}345(66.4) \\
175(33.6)\end{array}$ & $\begin{array}{l}294(68.7) \\
120(28.0)\end{array}$ & $\begin{array}{l}289(55.9) \\
222(42.9)\end{array}$ & 0.266 \\
\hline $\begin{array}{l}\text { Education } \\
\text { None } \\
\text { Primary } \\
\text { Secondary } \\
\text { Tertiary }\end{array}$ & $\begin{array}{c}131(8.9) \\
278(19.0) \\
406(27.7) \\
460(31.4)\end{array}$ & $\begin{array}{c}13(2.5) \\
96(18.5) \\
166(31.9) \\
219(42.1)\end{array}$ & $\begin{array}{c}63(14.7) \\
105(24.5) \\
97(22.7) \\
72(16.8)\end{array}$ & $\begin{array}{c}55(10.6) \\
77(14.9) \\
143(27.7) \\
169(32.7)\end{array}$ & $<0.001$ \\
\hline $\begin{array}{l}\text { Marital status } \\
\text { Single } \\
\text { Married } \\
\text { Divorced } \\
\text { Widowed }\end{array}$ & $\begin{array}{c}387(26.4) \\
886(60.5) \\
31(2.1) \\
76(5.2)\end{array}$ & $\begin{array}{c}138(26.5) \\
346(66.5) \\
11(2.1) \\
16(3.1)\end{array}$ & $\begin{array}{c}91(21.4) \\
238(55.6) \\
7(1.6) \\
34(7.9)\end{array}$ & $\begin{array}{c}158(30.6) \\
302(58.4) \\
13(2.5) \\
26(5.0)\end{array}$ & $<0.001$ \\
\hline
\end{tabular}

Table 1: Characteristics of the study population $(\mathrm{N}=1,465)$.

\section{HIV Knowledge Items}

Knowledge of HIV

Ever heard of HIV?

Can you tell a HIV-infected person from his/her appearance?

Does HIV cause life-long infection?

Is HIV more easily transmitted than Hepatitis B virus?

Knowledge of HIV transmission

Can HIV be transmitted through

Blood transfusion?

Sexual intercourse?

Breastfeeding?

From infected mother to unborn child?

Sharing razor blade, nail cutter, clipper?

Sharing toothbrush with infected persons?

Scarification marks and tattoos?

Male or female traditional circumcision?

*Sharing food with HIV infected person?

*Eating food cooked by HIV infected person?

*Hugging?

Kissing?

*Hand shaking?

*Mosquito bites?

*Witchcraft?

Knowledge of HIV prevention and control

Can HIV be prevented;

Through vaccination?

Screening of pregnant women?

If HIV positive pregnant women receive treatment?

'If infants born to HIV positive mothers receive vaccination and immunoglobulin at birth?

If HIV positive mothers do not breastfeed their babies?

If family members of HIV patients are screened for HIV?

Is there a medical treatment for HIV?

*Is there a possibility of a cure of HIV?

"A score of 1 was given to "NO" responses while a score of 0 was given to "YES" responses

\begin{tabular}{|c|c|}
\hline Yes N (\%) & No N (\%) \\
\hline $\begin{array}{c}1,342(91.6) \\
485(33.1) \\
759(51.8) \\
620(42.3)\end{array}$ & $\begin{array}{c}123(8.4) \\
980(66.9) \\
706(48.2) \\
845(57.7)\end{array}$ \\
\hline $\begin{array}{c}1,289(88.0) \\
1,321(90.2) \\
1,180(80.5) \\
1,164(79.5) \\
1,283(87.6) \\
1,138(77.7) \\
1,062(72.5) \\
1,078(73.6) \\
1,043(71.2) \\
1,137(77.6) \\
1,144(78.1) \\
724(49.4) \\
1,154(78.8) \\
982(67.0) \\
916(62.5)\end{array}$ & $\begin{array}{c}176(12.0) \\
141(9.8) \\
285(19.5) \\
301(20.5) \\
182(12.4) \\
327(22.3) \\
403(27.5) \\
387(26.4) \\
422(28.8) \\
328(22.4) \\
321(21.9) \\
741(50.6) \\
311(21.2) \\
483(33.0) \\
549(37.5)\end{array}$ \\
\hline $\begin{array}{c}497(33.9) \\
1,188(81.1) \\
1,090(74.4)\end{array}$ & $\begin{array}{l}968(66.1) \\
277(18.9) \\
375(25.6)\end{array}$ \\
\hline $\begin{array}{l}945(64.5) \\
874(59.7) \\
194(13.2) \\
992(67.7) \\
638(43.5)\end{array}$ & $\begin{array}{c}520(35.5) \\
591(40.3) \\
1,271(86.8) \\
473(32.3) \\
827(56.5)\end{array}$ \\
\hline
\end{tabular}

Table 2: Knowledge of the nature, prevention and transmission of HIV $(n=1,465)$.

of HIV prevention and control, majority believed that prevention of mother-to-child transmission by treating positive mothers was effective while only $13 \%$ agreed that screening family members of HIV positive persons was of any benefit. Responses to other knowledge questions are shown in Table 2.

Tables 3 and 4 depict responses to attitude and practice questions towards PLWHA with majority, especially from the southern district, agreeing to the negative attitude and practice statements of not living (73\%), eating (71.3\%), working (74\%) or marrying (77\%) a person with a positive HIV status.
Median scores of the knowledge of HIV varied significantly with age, level of education and marital status $(p<0.05)$. Older persons, those without formal education, the widowed and divorced tended to have lower scores. Attitude scores also showed significant variation with age, level of education and senatorial districts with young persons, those without formal education and persons resident in the southern senatorial district having lower scores $(\mathrm{p}<0.05)$. Practice scores did not show any significant variation with social demographic characteristics (Table 5). There was a significant correlation between knowledge, attitude and practice scores $(\mathrm{p}<0.05)$. 


\section{Discussion}

HIV remains a major public health problem in CRS and indeed Nigeria in spite of the concerted efforts by government to curb it over the last decade. Our study showed a good knowledge of HIV amongst residents of the three senatorial districts in Cross river state. While knowledge of the common routes of HIV transmission such as sexual intercourse, blood transfusion, sharing of sharps, scarification and tattooing was high, misconceptions that HIV can be transmitted through hugging, hand shake, mosquito bites and witch craft was also common. This finding is similar to what was reported in Benin city over a decade ago amongst civil servants and more recently among young persons in CRS and other developing countries such as Ghana, Lao Peoples Democratic

\begin{tabular}{|l|c|c|}
\hline HIV Attitude Items & $\begin{array}{c}\text { Agree } \\
\text { N (\%) }\end{array}$ & $\begin{array}{c}\text { Disagree } \\
\text { N (\%) }\end{array}$ \\
\hline Non-infected persons should not: & & \\
Live with HIV positive persons in the same house & $1,070(73.0)$ & $395(27.0)$ \\
Share cooking utensils with HIV patients & $987(67.4)$ & $478(32.6)$ \\
Eat food with HIV patients & $1,044(71.3)$ & $421(28.7)$ \\
Use the same toilet as HIV patients & $959(65.5)$ & $506(34.5)$ \\
Work in the same office as HIV patients & $1,084(74.0)$ & $381(26.0)$ \\
\hline
\end{tabular}

A score of 1 was given to 'disagree' while a score of 0 was given to 'agree' Table 3: Attitude towards persons living with HIV ( $n=1,465)$.

\begin{tabular}{|l|c|c|}
\hline HIV Practice Items & Yes & No \\
& N (\%) & N (\%) \\
\hline Should non-infected persons: & & \\
Take care of persons living with HIV & 1,006 & $459(31.3)$ \\
Marry persons living with HIV & $(68.7)$ & $1,126(76.9)$ \\
"Assist injured HIV patient with open wound without & $339(23.1)$ & $518(35.4)$ \\
using gloves & $947(64.6)$ & \\
\hline
\end{tabular}

A score of 1 was given to 'yes' while a score of 0 was given to 'no' *Indicates variables in which a score of 1 was assigned to 'No' response, while a score of 0 was assigned to 'yes' responses

Table 4: Practices related to persons living with HIV $(n=1,465)$.
Republic, and Afghanistan [14,21-24]. In 2014, the Nigerian Bureau of Statistics reported that only $32 \%$ of the adult population in Nigeria had comprehensive knowledge of HIV transmission and prevention [25] This is an indication of not only the need for more information and education of the general public concerning transmission of HIV but more importantly, the need to incorporate the services of care managers (nurses trained specifically on prevention, treatment and lifestyle modifications for HIV positive persons) into the voluntary counseling and treatment (VCT) centers to support physicians, family members and care givers in their management and interactions with PLWHA. This will minimize misconceptions surrounding the transmission of HIV and improve attitudes and behaviour towards PLWHA. Ciccone et al. [26] demonstrated that incorporating care managers into the health care system for the management of chronic diseases improved patient's knowledge, self-efficacy and disease outcome.

Age varied significantly with knowledge with those aged 18-27years and above 57 years having lower scores. Persons in the former age group are more likely to be single while those in the later are more likely to have lost their partners considering the average life span of Nigerians is estimated at 52 years [25]. Nigeria remains a very moralistic society where sexual relationships receive societal approval only in the context of marriage and for procreation. This could affect the freedom of persons outside of marriage especially the younger age group to openly seek information about HIV against societal expectations [27] Although education on HIV and related sexually transmitted diseases was recently incorporated in the Nigerian curriculum for primary and secondary schools, lack of adequately qualified teachers and counselors is a major challenge [28].

Majority of the respondents showed a negative attitude towards PLWHA which was more pronounced in the younger age group, persons with moderate education and those from the southern senatorial districts. The finding of a negative attitude towards PLWHA

\begin{tabular}{|c|c|c|c|c|c|c|c|}
\hline Variable & $\begin{array}{c}N \\
(1,465)\end{array}$ & $\begin{array}{l}\text { Knowledge score } \\
\text { Median (IQR) }\end{array}$ & P-value & $\begin{array}{l}\text { Attitude score } \\
\text { Median (IQR) }\end{array}$ & $\mathrm{P}$-value & $\begin{array}{l}\text { Practice score } \\
\text { Median (IQR) }\end{array}$ & P-value \\
\hline $\begin{array}{l}\text { Age group (years) } \\
18-27 \\
28-37 \\
38-47 \\
48-57 \\
>57 \\
\text { Missing }\end{array}$ & $\begin{array}{c}373 \\
315 \\
318 \\
216 \\
168 \\
75\end{array}$ & $\begin{array}{c}19(15-22) \\
20(16-22) \\
20(16-22) \\
20(16.5-21) \\
18.5(14-21) \\
19(16-22)\end{array}$ & 0.003 & $\begin{array}{c}4(1-5) \\
5(2-5) \\
5(2-5) \\
4(4-5) \\
5(1.5-5) \\
5(1.5-5)\end{array}$ & $<0.001$ & $\begin{array}{l}2(1-2) \\
2(1-2) \\
2(1-2) \\
2(1-2) \\
2(1-2) \\
2(1-2)\end{array}$ & 0.412 \\
\hline $\begin{array}{l}\text { Sex } \\
\text { Female } \\
\text { Male } \\
\text { Missing }\end{array}$ & $\begin{array}{c}928 \\
517 \\
20\end{array}$ & $\begin{array}{c}20(16-22) \\
20(16-22) \\
18(13.5-21.5)\end{array}$ & 0.882 & $\begin{array}{c}5(2-5) \\
5(2-5) \\
5(1.5-5)\end{array}$ & 0.752 & $\begin{array}{l}2(1-2) \\
2(1-2) \\
2(1-2)\end{array}$ & 0.149 \\
\hline $\begin{array}{l}\text { Education } \\
\text { None } \\
\text { Primary } \\
\text { Secondary } \\
\text { Tertiary } \\
\text { Missing }\end{array}$ & $\begin{array}{l}131 \\
278 \\
406 \\
460 \\
190\end{array}$ & $\begin{array}{l}17(11-20) \\
19(14-21) \\
19(15-21) \\
21(18-22) \\
20(16-23)\end{array}$ & 0.0001 & $\begin{array}{l}4(0-4) \\
5(1-5) \\
4(2-5) \\
5(3-5) \\
5(3-5)\end{array}$ & $<0.001$ & $\begin{array}{l}2(1-2) \\
2(1-2) \\
2(1-2) \\
2(1-2) \\
2(1-2)\end{array}$ & 0.213 \\
\hline $\begin{array}{l}\text { Marital status } \\
\text { Single } \\
\text { Married } \\
\text { Divorced } \\
\text { Widowed } \\
\text { Missing }\end{array}$ & $\begin{array}{c}387 \\
886 \\
31 \\
76 \\
85\end{array}$ & $\begin{array}{c}20(16-23) \\
20(16-22) \\
18(12-21) \\
19(14.5-21) \\
20(17-22)\end{array}$ & 0.029 & $\begin{array}{c}5(2-5) \\
5(2-5) \\
3(0-5) \\
5(1.5-5) \\
5(4-5)\end{array}$ & 0.235 & $\begin{array}{l}2(1-2) \\
2(1-2) \\
2(1-2) \\
2(1-2) \\
2(1-2)\end{array}$ & 0.436 \\
\hline $\begin{array}{l}\text { Senatorial District } \\
\text { Southern } \\
\text { Central } \\
\text { Northern }\end{array}$ & $\begin{array}{l}520 \\
428 \\
517\end{array}$ & $\begin{array}{l}20(16-22) \\
20(17-22) \\
20(16-22)\end{array}$ & 0.002 & $\begin{array}{l}4(1-5) \\
5(3-5) \\
5(2-5)\end{array}$ & $<0.001$ & $\begin{array}{l}2(1-2) \\
2(1-2) \\
2(1-2)\end{array}$ & 0.558 \\
\hline
\end{tabular}

*Kruskal-Wallis test was used to detect a significant difference association of socio-demographic variables with the median KAP HIV scores

Table 5: Comparison of demographic characteristics and median KAP HIV scores. 
among the younger age group and people with low levels of education is not peculiar to our study. Similar results were reported in studies amongst youths in Nigeria and Tanzania [29,30]. This may be due to fear of contracting the infection and stigmatization associated with being HIV positive. Ignorance, anxiety and fear of stigmatization have been identified as major barriers to the acquisition of accurate information on HIV and promote denial [31]. These concerns need to be addressed urgently to improve the acceptance of PLWHA in our communities and promote voluntary counseling and testing for HIV. The southern senatorial district is an urban area compared to the central and northern senatorial districts. The lower attitude scores in the southern district may probably be a reflection of the individualistic lifestyle of city dwellers as opposed to the communal lifestyle of rural dwellers which encourages willingness to assist the sick.

\section{Conclusion}

In conclusion, this study shows that although the awareness of HIV and its major routes of transmission are high in CRS, there are gaps in the knowledge of the consequences of HIV and misconceptions about modes of transmission. There is need to develop community based inter-generational preventive programmes and incorporate care managers in VCT centers to address barriers in communication and promote self-efficacy of PLWHA.

\section{Limitations}

Our study had some limitations. The use of questionnaires with structured questions requiring a pre-defined response (yes/no, agree/ disagree) made it difficult to evaluate participants' personal perception on knowledge of HIV infection that informed their attitude and practice choices. Thus, the study did not identify the reason/s for the reported knowledge gaps and cannot establish a causal relation between knowledge, attitude and practices.

\section{References}

1. UNAIDS (2016) Global AIDS update.

2. UNAIDS (2014) Joint United Nations Programme on HIVIAIDS

3. UNAIDS (2014) Epidemiology fact sheet of HIV and AIDS in Nigeria.

4. Nigeria Federal Ministry of Health (2013) National HIV and AIDS and Reproductive survey.

5. Nigeria National agency for the control of AIDS (2014) Country progress report.

6. Ankomah A (2011) HIV related risk perception among female sex workers in Nigeria. HIVIAIDS - Research and palliative care 3: 93-100

7. http://www.sbccvch.naca.gov.ng/

8. Nigerian Federal Ministry of Health (2010) HIV integrated biological and behavioral surveillance survey (IBBSS).

9. Nigerian Federal Ministry of Health (2013) National HIVIAIDS and Reproductive Health Survey 2012, NARHS plus II.

10. Eluwa GI (2013) A profile of HIV prevalence and risk behavior among injection drug users in Nigeria; Should we be alarmed? Drug Alcohol Depend 127: 65-71

11. Harm reduction International (2014) Global state of harm reduction report.
12. World Health Organization (2016) Mother-to-child transmission of HIV.

13. Ubesie AC, Emodi IJ, Ikefuna AN, Ilechukwu GC, Ilechukwu GCA (2012) Prevalence of human immunodeficiency virus among transfused children with sickle cell anemia in Enugu, Nigeria. Ann Med Health Sci Res 2: 109-113.

14. Okojie $\mathrm{OH}$, Ogbeide O, Nwulia A (1995) Knowledge, attitude and practice towards AIDS among civil servants in Nigeria. J R Soc Health 115: 19-22.

15. Durojaiye OC (2011) Knowledge, attitude and practice of HIVIAIDS: Behavior change among tertiary education students in Lagos, Nigeria. Ann Trop Med Public Health 4: 18-24.

16. Adebamowo CA, Ezeome ER, Ajuwon JA, Ogundiran TO (2002) Survey of the knowledge, attitude and practice of Nigerian surgery trainees to HIV-infected persons and AIDS patients. BMC Surg 2: 7.

17. Saliu A, Akintunde B (2014) Knowledge, attitude and preventive practices towards HIV among prison inmates in Ogbomosho, Oyo State, South-west Nigeria. Int J Reprod Med.

18. Saob AE, Fawole AO, Sadoh WE, Oladimeji AO, Sotiloye OS (2006) Attitude of health-care workers to HIVIAIDS. Afr J Reprod Health 10: 39-46.

19. Adekunbi AF, Nwozichi CU, Ojediran TD (2015) Knowledge, attitude and practice of HIVIAIDS-related stigma and discrimination reduction among nursing students in southwest Nigeria. Iran J Nurs Midwifery Res 20: 705-711.

20. World Health Organization, United Nations (2016) Sustainable Development Summit 2015

21. Osonwa OK, Ogbuagu UR, Iyam MA, Osuchukwu NC, Eko JE, et al. (2013) Knowledge, attitude and risk perception of HIVIAIDS among youths in Calabar Cross River State, Nigeria. IOSR J Hum Soc Sci 7: 1-8.

22. Sallar AM (2009) Correlates of misperceptions in HIV knowledge and attitude towards people living with HIVIAIDS (PLHIV) among in-school and out-ofschool adolescents in Ghana. Afr Health Sci 9: 82-91.

23. Thanavanh B, Harun-Or-Rashid M, Kasuya H, Sakamoto J (2013) Knowledge attitudes and practices regarding HIVIAIDS among male high school students in Lao People's Democratic Republic. J Int AIDS Soci 16: 17387.

24. Mansoor AB, Fungladda W, Kaewkungwal J, Wongwit W (2008) Gende differences in KAP related to HIVIAIDS among freshmen in Afghan universities. Southeast Asian J Trop Med Public Health 39: 404-418.

25. National Bureau of Statistics, Federal Ministry of Health (2016) The millennium development goals performance tracking survey report 2014. MDG survey report.

26. Ciccone MM, Aquilino A, Cortese F, Scicchitano P, Sassara M, et al. (2010) Feasibility and effectiveness of a disease and care management model in the primary health care system for patients with heart failure and diabetes (Project Leonardo). Vasc Health Risk Manag 6: 297-305.

27. Smith DJ (2013) Imagining HIVIAIDS; Morality and perceptions of personal risk in Nigeria. Med Anthropol 22: 343- 372.

28. Abba RC (2013) The universal basic education programme and the family life HIV education in Nigeria. International Journal of Development and Sustainability 2: 766-776.

29. Aomreore AA, Alikor EA, Nkanginieme KE (2004) Survey of knowledge of HIV infection among senior secondary school 3 (SSS3) students in Port Harcourt. Niger J Med 13: 398-404.

30. Kamala BA, Aboud S (2006) Knowledge, attitudes and practices on HIV prevention among secondary school students in Bukoba rural, Kagera regionTanzania. Dar es Salaam Med Students J 14: 14-18

31. Paul-Ebhohimhen VA, Poobalan A, Van Teijlingen ER (2008) A systematic review of school based sexual health interventions to prevent STI/HIV in SubSaharan Africa. BMC Public Health 8: 1-13. 